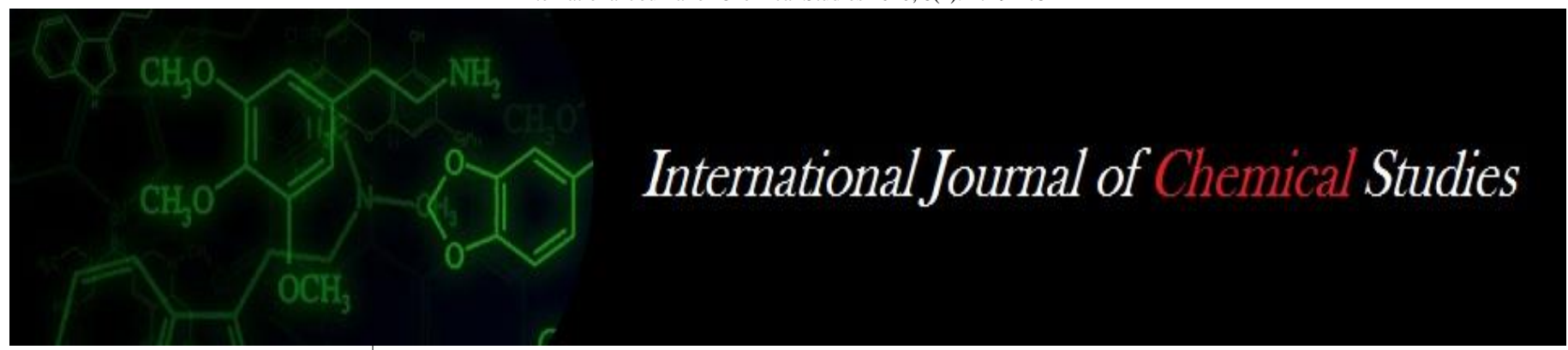

P-ISSN: 2349-8528

E-ISSN: 2321-4902

www.chemijournal.com

IJCS 2020; 8(4): 2749-2752

(C) 2020 IJCS

Received: 28-05-2020

Accepted: 30-06-2020

G Lal

Director, ICAR-Nationa

Research Centre on Seed Spices,

Tabiji, Ajmer, Rajasthan, India

S Lal

Sr. Scientist, ICAR-National

Research Centre on Seed Spices,

Tabiji, Ajmer, Rajasthan, India

MK Choudhary

SRF, ICAR-National Research Centre on Seed Spices, Tabiji,

Ajmer, Rajasthan, India

\section{RS Meena}

Senior Scientist, ICAR-Nationa Research Centre on Seed Spices, Tabiji, Ajmer, Rajasthan, India

Neha Shekhawat

Young Professional, AINPOF, ICAR-National Research Centre on Seed Spices, Tabiji, Ajmer,

Rajasthan, India
Corresponding Author:

S Lal

Sr. Scientist, ICAR-National

Research Centre on Seed Spices,

Tabiji, Ajmer, Rajasthan, India

\section{Growth, yield and essential oil of coriander (Coriandrum sativum $\mathrm{L}$.) variety ACr-2 as influenced by various nutrient levels and crop geometry}

\author{
G Lal, S Lal, MK Choudhary, RS Meena and Neha Shekhawat
}

DOI: https://doi.org/10.22271/chemi.2020.v8.i4af.10062

\begin{abstract}
A field experiment was carried out Rabi season of 2017-18 at research farm of ICAR-NRCSS, Ajmer, Rajasthan to study the growth, yield and essential oil characterization of coriander variety Ajmer Coriander-2 (ACr-2) as influenced by nutrient levels and crop geometry. The experiment was laid out in Factorial Randomized Block Design with four replications. The experiment was comprises three treatment of each crop geometry and nutrient management. Crop geometry $\mathrm{G}_{1}(30 \mathrm{~cm} \times 15 \mathrm{~cm}), \mathrm{G}_{2}(30$ $\mathrm{cm} \times 10 \mathrm{~cm})$ and $\mathrm{G}_{3}(30 \mathrm{~cm} \times 5 \mathrm{~cm})$ with nutrient levels $\mathrm{N}, \mathrm{P}_{2} \mathrm{O}_{5}$ and $\mathrm{K}_{2} \mathrm{O}$ of kg/ha $\mathrm{F}_{1}(40: 20: 10), \mathrm{F}_{2}$ $(50: 25: 15)$ and $F_{3}(60: 30: 20)$. The results revealed that the maximum plant height $(91.38 \mathrm{~cm})$, primary branches per plant (10.90) and secondary branches per plant (13.28) were recorded with application of 60:30:20 kg/ha NPK and crop geometry of $30 \mathrm{~cm}$ x $10 \mathrm{~cm}$. Similar trends were found in yield attributes like number of umbel per plant (34.09) and number of umbellates per umbel (5.91). Seed yield per hectare $(1271.25 \mathrm{~kg} / \mathrm{ha})$ and essential oil yield $(6.74 \mathrm{~kg} / \mathrm{ha})$ was also observed with application of 60:30:20 kg/ha NPK with crop geometry of $30 \mathrm{~cm} \times 10 \mathrm{~cm}$. Based on the results it is concluded that nutritional level of 60:30:20 kg/ha NPK with crop geometry of $30 \mathrm{~cm} \times 10 \mathrm{~cm}$ is better for realizing higher seed yields of coriander variety ACr-2.
\end{abstract}

Keywords: Coriander, crop geometry, fertilizer levels, essential oil, seed yield

\section{Introduction}

Coriander (Coriandrum sativum L.) is a major seed spice crop belonging to Apiacae family. In India it is mainly cultivated in Rajasthan, MP, Gujarat, Assam and Karnataka. Rajasthan ranks second in area and production of coriander in our country followed by Gujarat (DASD, 201718). Green leaf is having high essential oil with good aroma and flavour Lal et al. (2018) ${ }^{[7]}$. The essential oil content in seeds of coriander is $0.47-0.53$ per cent whereas major chemical constituents of essential oil are linalool, linalyl acetate along with other important constituents such as thymol, geraniol, carophyllene and pinene. It has traditionally been used for its antiinflammatory, anti-diabetic, cholesterol lowering effects and also a good appetizer. Health benefits of coriander include treatment of swellings, diarrhoea, mouth ulcers, anaemia, digestion, menstrual disorders, small pox, eye care, conjunctivitis, skin disorders, blood sugar disorders, protects and soothes liver etc Diwan et al. (2018) ${ }^{[1]}$. The various agronomic practices such as application of nitrogen fertilization and plant spacing are the important deciding factors influencing growth and yield parameters of coriander. Coriander plant could be used as indicator plant for rapid determination of N, P and K deficiency of Indian soils. Optimum crop geometry is one of the important factors for crop growth and production because of efficient utilization of resources Nayak et al. (2013) ${ }^{[15]}$. The yield of coriander could be achieved largely by providing the most optimum plant population per unit area and balanced nutrient under field conditions, which could be provided by optimizing the spacing. The plants grown in the wider spacing exhibit more horizontal and continuous vegetative growth due to less population pressure per unit area. Therefore, they give fewer yields per unit area Kumar (2004) ${ }^{[5]}$. However, plants grown under normal spacing will have optimum population density per unit area which provides optimum conditions for luxuriant crop growth and better plant canopy area due to maximum light interception, photosynthetic activity, 
assimilation and accumulation of more photosynthates into plant system and hence they produce more seed yield with best quality traits Mazumdar et al. (2007) ${ }^{[9]}$. Optimum crop geometry is one of the important factors for crop growth and production because of efficient utilization of resources. Very limited information on integrated management of nutrients along with crop geometry is available. Therefore the present investigation was initiated with the aim to evaluate growth and yield of coriander as influenced by different levels of nutrition and plant spacing. Since, $\mathrm{ACr}-2$ is a new emerging variety of coriander especially for seed production, the standardization of proper fertilizer dose and crop geometry is very essential to enhance the seed yield and produce quality.

\section{Materials and Methods}

The field experiment on growth and yield of coriander as influenced by nutrient levels with varying crop geometry was conducted at ICAR-NRCSS, Ajmer (Rajasthan) in Rabi season of 2017- 18. The experiment was laid out in Factorial Randomized Block Design with three doses of nitrogen, phosphorus and potash (N: $\mathrm{P}: \mathrm{K} \mathrm{kg} / \mathrm{ha})$ 40:20:10, 50:25:15 and 60:30:20 kg/ha, respectively) and three crop geometry (30 $\mathrm{x} 15,30 \times 10$ and $30 \times 5.0 \mathrm{~cm}$ ) with four replications. Sowing of coriander (var. Ajmer Coriander-2) using recommended seed rate as per treatments was done at $30 \mathrm{~cm}$ line to line spacing and keeping $15 \mathrm{~cm}, 10 \mathrm{~cm}$ and $5.0 \mathrm{~cm}$ plant to plant distance. Immediately after sowing light irrigation was applied for ensuring proper germination and establishment of the crop. Afterward each irrigation was applied for 15 days interval. $50 \%$ of total nitrogen and full dose of phosphorus and potash under study was provided at the time of sowing and remaining half nitrogen was divided in two equal splits and applied at 30 and 60 DAS. Five plants were selected randomly from each plot. Observations on plant height, branches per plant, yield attributing characters viz. umbel per plant, umbellate per umbel and seed yield were recorded. Results were consistent during all the one years. Hence, the results were discussed based on pooled analysis. The statistical analysis was done as per the procedure suggested by Panse and Sukhatme (1985) ${ }^{[16]}$.

\section{Results and Discussion \\ Response of different spacing on growth and yield}

During the investigation, all the growth parameters and yield except plant height was significantly affected by different crop geometry. Data are presented in the Table 1. Significantly higher growth parameters and yield attributes like plant height at harvest $(89.02 \mathrm{~cm})$, number of primary branches per plant (10.56), number of secondary branches per plant (12.28) and yield attributes umbels per plant (30.51), umbellates per umbel (5.59), seed yield (1134.10 kg/ha), essential oil in seed $(0.50 \%)$ and essential oil yield $(5.73$ $\mathrm{kg} / \mathrm{ha}$ ) were obtained by maintaining the crop geometry $(30 \mathrm{x}$ $10 \mathrm{~cm}$ ) spacing between rows and plants which may be due to efficient utilization of growth factors like nutrients and sunlight. Increase in number of umbels per plant with the decrease in plant density by increasing the space between rows Nath et al. (2008) ${ }^{[14]}$. The larger canopy development associated with profuse branching has increased interception, absorption and utilization of solar energy resulting in formation of higher photosynthates Diwan et al. (2018) [1]. The reasons for increase in yield attributing characters may be due to wider plant spacing resulted in less interplant competition for space, light, nutrients and moisture. The seed and straw yield were significantly decreased with increase in plant spacing.

The full yield potential of individual plant is achieved when sown at wider spacing. Marked improvement in yield and yield attributes of the crop with increase in spacing appear to be on account of vigorous growth of the plants as evident from profuse branching and higher biomass accumulation per plant. The profuse branching seem to have led to greater initiation of flowering and adequate supply of metabolites due to the increase in biomass per plant might have helped in retention of flower thereby greater seed formation and seed growth. These results justify that overcrowding of plants at closer spacing significantly reduced growth and yield attributes of the crop but compensated the yield to a certain level. On the other hand, due to more plants/unit area though, improved overall growth of crop but failed to record highest yield due to less number of plants per hectare. The effect of different crop geometry was also statistically higher for seed yield of the coriander. The results were in close conformity with (Jamali et al. (2013) ${ }^{[4]}$, Kumar et al. (2006) ${ }^{[6]}$, Patel et al. (2013) [17], Moniruzzaman et al. (2013) [13], Shanu et al. (2013) ${ }^{[19]}$, Sharma et al. (2016) ${ }^{[21]}$ in coriander.

\section{Response of different fertilizer levels on growth and yield}

Data presented in Table 1 revealed that significantly higher growth parameters and yield attributes like plant height at harvest $(88.12 \mathrm{~cm})$, number of primary branches per plant (9.72), number of secondary branches per plant (12.02) and yield attributes umbels per plant (28.16), umbellates per umbel (5.59), seed yield (1096.32 kg/ha), essential oil in seed $(0.51 \%)$ and essential oil yield $(5.59 \mathrm{~kg} / \mathrm{ha})$ was obtained by supplying the nutritional requirement of $(60: 30: 20 \mathrm{~kg}$ NPK/ha. This might be due to adequate supply of nitrogen associated with high photosynthetic activity leading to vigorous vegetative growth and physiologically more stout and healthy plant morphology. It is an established fact that nitrogen is required for the synthesis of protein, chlorophyll and other organic compounds of physiological significance. Thus, increased level of nitrogen in plant by virtue of its increased availability in the soil medium and there after efficient absorption and translocation in various growth by way of active cell division and elongation resulting in greater plant height and number of branches. The nitrogen application might have resulted in larger canopy development and presumably higher chlorophyll content of leaves as nitrogen actively participate in its formation with profound influence on photosynthetic efficiency of plants, this might had led to higher accumulation of fresh and dry matter. The findings of this investigation were in close conformity with (Ghosh (2009) [2], Jamali and Martirosyan (2013) ${ }^{[4]}$, Lal et al. (2016) ${ }^{[8]}$, Mehta et al. (2013) ${ }^{[12]}$, Patel et al. (2013) ${ }^{[17]}$, Pooja et al. (2017) [18], Shanu et al. (2013) ${ }^{[19]}$, Sharangi et al. (2011) ${ }^{[20],}$ Sharma et al. (2016) ${ }^{[21]}$, Tehlan and Thakral (2008) ${ }^{[24]}$ in coriander and Meena et al. (2015) ${ }^{[10]}$ in anise.

\section{Interaction effect on growth, seed yield and essential oil content}

Data presented in Table 1 revealed that growth and yield were significantly influenced by interaction effects of crop geometry and nutritional level. The growth attributes like plant height at harvest $(91.38 \mathrm{~cm})$, number of primary branches per plant (10.90), number of secondary branches per plant (13.28) and yield attributes viz. umbels per plant (34.09), umbellates per umbel (5.91) maximum seed yield $(1271.25 \mathrm{~kg} / \mathrm{ha})$, maximum essential oil percentage $(0.53 \%)$ 
and essential oil yield $(6.74 \mathrm{~kg} / \mathrm{ha})$ was found to maximum in crop geometry $\mathrm{G}_{2} \mathrm{~F}_{3}(30 \mathrm{~cm} \times 10 \mathrm{~cm})$ with nutritional levels (60:30:20 NPK kg per ha) followed by $\mathrm{G}_{2} \mathrm{~F}_{2}(30 \mathrm{~cm} \times 10 \mathrm{~cm})$ with nutritional levels (50:25:15 NPK kg per ha) the seed yield (1100.63 kg per ha) and yield of essential oil (5.58 $\mathrm{kg} / \mathrm{ha}$ ). The yield increase with higher nitrogen rates at closer spacing could be due to maximum dry matter production for grain filling that was made possible as a result of taller plants that trapped most of the photosynthetically active radiation, more number of leaves per plant that provided more surfaces for photosynthesis and assimilates production. The results were in close conformity with Tatero and Ojima (1973) ${ }^{[23]}$. Considering the main effect and the interaction, closer spacing seems to favour the growth and yield of coriander. Similar observation was also reported by (Diwan et al. (2018) ${ }^{[1]}$, Mehta et al. (2012) ${ }^{[11]}$ and Singh et al. (2005) ${ }^{[22]}$ in okra.

Table 1: Growth, yield attributing characters and essential oil of coriander variety ACr-2 as influenced by nutrient levels and crop geometry

\begin{tabular}{|c|c|c|c|c|c|c|c|c|}
\hline Treatment & $\left|\begin{array}{c}\text { Plant height } \\
(\mathrm{cm})\end{array}\right|$ & $\begin{array}{l}\text { No. of primary } \\
\text { branches/plant }\end{array}$ & $\begin{array}{l}\text { No. of secondary } \\
\text { branches /plant }\end{array}$ & \begin{tabular}{|c|}
$\begin{array}{c}\text { No. of Umbel } \\
\text { /plant }\end{array}$ \\
\end{tabular} & $\begin{array}{c}\text { No. of umbellate } \\
\text { /umbel }\end{array}$ & \begin{tabular}{|c|}
$\begin{array}{c}\text { Seed yield } \\
(\mathrm{kg} / \mathrm{ha})\end{array}$ \\
\end{tabular} & $\begin{array}{c}\text { Essential } \\
\text { oil \% } \\
\end{array}$ & $\begin{array}{l}\text { Essential oil } \\
\text { yield kg/ha) }\end{array}$ \\
\hline \multicolumn{9}{|c|}{ Crop geometry } \\
\hline $\mathrm{G}_{1}$ & 86.33 & 10.04 & 11.28 & \begin{tabular}{|l|}
26.70 \\
\end{tabular} & 5.33 & 1012.01 & 0.47 & 4.72 \\
\hline $\mathrm{G}_{2}$ & 89.02 & 10.56 & 12.28 & 30.51 & 5.59 & 1134.10 & 0.50 & 5.73 \\
\hline $\mathrm{G}_{3}$ & 83.36 & 7.95 & 9.95 & 21.96 & 5.41 & 932.85 & 0.49 & 4.58 \\
\hline $\mathrm{S} \mathrm{Em} \pm$ & 0.52 & 0.09 & 0.42 & 0.51 & 0.15 & 35.60 & 0.01 & 0.21 \\
\hline $\mathrm{CD}(\mathrm{P}=0.05)$ & 1.51 & 0.25 & 1.23 & 1.49 & 0.45 & 103.90 & 0.04 & 0.63 \\
\hline \multicolumn{9}{|c|}{ Nutritional levels } \\
\hline $\mathrm{F}_{1}$ & 84.03 & 9.34 & 9.87 & 24.40 & 5.31 & 970.07 & 0.46 & 4.50 \\
\hline $\mathrm{F}_{2}$ & 86.56 & 9.50 & 11.62 & 26.61 & 5.42 & 1012.57 & 0.49 & 4.94 \\
\hline $\mathrm{F}_{3}$ & 88.12 & 9.72 & 12.02 & 28.16 & 5.59 & 1096.32 & 0.51 & 5.59 \\
\hline $\mathrm{S} \mathrm{Em} \pm$ & 0.52 & 0.09 & 0.42 & 0.51 & 0.15 & 35.60 & 0.01 & 0.21 \\
\hline $\mathrm{CD}(\mathrm{P}=0.05)$ & 1.51 & 0.25 & 1.23 & 1.49 & 0.45 & 103.90 & 0.04 & 0.63 \\
\hline \multicolumn{9}{|c|}{ Interaction } \\
\hline $\mathrm{G}_{1} \mathrm{~F}_{1}$ & 84.69 & 9.93 & 9.53 & 24.95 & 5.28 & 955.63 & 0.44 & 4.20 \\
\hline $\mathrm{G}_{1} \mathrm{~F}_{2}$ & 86.96 & 10.01 & 12.28 & 27.00 & 5.40 & 1009.58 & 0.47 & 4.68 \\
\hline $\mathrm{G}_{1} \mathrm{~F}_{3}$ & 87.36 & 10.20 & 12.03 & 28.14 & 5.30 & 1070.83 & 0.49 & 5.29 \\
\hline $\mathrm{G}_{2} \mathrm{~F}_{1}$ & 86.51 & 10.25 & 11.04 & 27.90 & 5.50 & 1030.42 & 0.47 & 4.87 \\
\hline $\mathrm{G}_{2} \mathrm{~F}_{2}$ & 89.17 & 10.55 & 12.54 & 29.54 & 5.35 & 1100.63 & 0.50 & 5.58 \\
\hline $\mathrm{G}_{2} \mathrm{~F}_{3}$ & 91.38 & 10.90 & 13.28 & 34.09 & 5.91 & 1271.25 & 0.53 & 6.74 \\
\hline $\mathrm{G}_{3} \mathrm{~F}_{1}$ & 80.88 & 7.85 & 9.04 & 20.35 & 5.15 & 924.17 & 0.47 & 4.42 \\
\hline $\mathrm{G}_{3} \mathrm{~F}_{2}$ & 83.55 & 7.95 & 10.04 & 23.29 & 5.50 & 927.50 & 0.49 & 4.58 \\
\hline $\mathrm{G}_{3} \mathrm{~F}_{3}$ & 85.63 & 8.07 & 10.76 & 22.25 & 5.58 & 946.88 & 0.50 & 4.75 \\
\hline S Em \pm & 0.90 & 0.15 & 0.73 & 0.89 & 0.27 & 61.66 & 0.03 & 0.37 \\
\hline $\mathrm{CD}(\mathrm{P}=0.05)$ & 2.62 & 0.43 & 2.14 & 2.59 & 0.78 & 179.95 & NS & 1.09 \\
\hline $\mathrm{CV} \%$ & 2.08 & 3.11 & 13.13 & 6.71 & 9.80 & 12.02 & 10.48 & 14.85 \\
\hline
\end{tabular}

Nutritional dose i.e $\mathrm{F}_{1}(40: 20: 10), \mathrm{F}_{2}(50: 25: 15)$ and $\mathrm{F}_{3}(60: 30: 20) \mathrm{NPK} \mathrm{kg} \mathrm{ha}^{-1}$ and crop geometry i.e $\mathrm{G}_{1}(30 \times 15 \mathrm{~cm}), \mathrm{G}_{2}(30 \times 10 \mathrm{~cm})$ and $\mathrm{G}_{3}$ $(30 \times 5.0 \mathrm{~cm})$

\section{Conclusion}

Based on study finding it can be concluded that to get maximum quality produce coriander should be planted in 30 $\mathrm{cm} \times 10 \mathrm{~cm}$ with nutritional level of 60:30:20 NPK kg per ha in semi arid agro-climatic condition.

\section{References}

1. Diwan G, Bisen BP, Maida P. Effect of nitrogen doses and row spacing on growth and seed yield of coriander (Coriandrum sativum L.). International Journal of Chemical Studies. 2018; 6(4):2768-2772.

2. Ghosh DK. Performance of coriander at different doses of nitrogen fertilizer under coconut based cropping system. Indian Coconut J. 2009; 51(9):6-10.

3. https://dasd.gov.in database 2017-18.

4. Jamali MM, Martirosyan. Evaluation of the effect of water deficit and chemical fertilizers on some characteristics of coriander (Coriandrum sativum L). International J Agro. and Plant prod. 2013; 4(3):413-417.

5. Kumar A. Standardization of seed production techniques in fenugreek. M. Sc. (Agri.) Thesis, Uni. of Agric. Sci. Dharwad (India), 2004.

6. Kumar K, Singh GP, Singh N, Nehra BK. Effect of row spacing and cycocel on growth and seed yield of coriander (Coriadnrum sativum L.) cv. Hisar Anand. Haryana J Horti. Sci. 2006; 35(3, 4):350.
7. Lal G, Meena RS, Choudhary MK. Evalution of coriander varieties for green leaf yield in off season under shade nets. Int. J Seed Spices. 2018; 8(2):12-16.

8. Lal G, Mehta RS, Singh SR, Kakani RK, Meena NK, Maheria SP. Effects of nitrogen levels on plant growth and leaf yield of off season coriander under shade nets. Int. J Seed Spices. 2016; 6(2):46-49.

9. Mazumdar SN, Moninuzzaman M, Rahman SMM, Basak NC. Influence of support systems and spacing on hyacinth bean production in the eastern hilly area of Bangladesh. Legume Research. 2007; 30(1):1-9.

10. Meena RL, Meena SS, Mehta RS, Meena RD, Saini Y. Response of varying nitrogen and phosphorus levels on growth and yield of Anise (Pimpinella anisum L.). Int. J of Seed Spices. 2015; 5(1):83-87.

11. Mehta RS, Anwer MM, Sharma YK. Effect of irrigation, nutrient levels and crop geometry on growth and yield of dill (Anethum sowa L.) Journal of Spices and Aromatic Crops. 2012; 21(1):20-24.

12. Mehta RS, Lal G, Vishal MK. Growth and yield of coriander (Coriandrum sativum L) as influenced by irrigation and nutrient levels with varying crop geometry. Ann. Agric. Res. New Series. 2013; 34(3):205-209.

13. Moniruzzaman M, Rahman MM, Hossain MM, Sirajul Harim AJM, Khaliq QA. Effect of seed rate and sowing method on foliage production of different genotypes of 
coriander (Coriandrum Sativum L.). Bangaldesh J Agril. Res. 2013; 38(3):435-445.

14. Nath prem, Jaiswal RC, Verma RB, Yadav GC. Effect of date of sowing, nitrogen levels and spacing on growth and yield of ajwain (Trachyspermum ammi L) Sprague. J of Spices and Aromatic Crops. 2008; 17(1):1-4.

15. Nayak BR, Samanta PK, Dashand AK, Swain SK. Growth and yield of coriander (Coriandrum sativum L.) as influenced by different levels of farm yard manure, nitrogen and plant spacing's. An Asian J of Soil Sci. 2013; 8(2):198-201.

16. Panse VG, Sukhatme PV. Statistical methods for Agricultural workers, $4^{\text {th }}$ Enlarged Edition, Indian Council of Agricultural Research Pub. 1985; New Delhi.

17. Patel CB, Amin AU, Patel AL. Effect of varying levels of nitrogen and sulphur on growth and yield of coriander (Coriandrum sativum L). The Bioscan. 2013; 4:12851289.

18. Pooja Nagre PK, Yadav H. Influence of different levels of nitrogen and phosphorus on seed yield and economics of coriander (Coriandrum sativum L.), J of Pharmacognosy and Phytochemical. 2017; 6(5):157-160.

19. Shanu IS, Naruka PP, Singh RP, Shaktawat S, Verma KS. Effect of seed treatment and foliar spray of thiourea on growth, yield and quality of coriander (Coriandrum sativum L.) under different irrigation levels. Int. J seed spices. 2013; 3(1):20-25.

20. Sharangi AB, Chatterjee R, Nanda MK, Kumar R. Growth and leaf yield dynamics of cool season coriander as influenced by cutting and foliar nitrogen application. J Plant Nutrition. 2011; 34(12):1762-1768.

21. Sharma A, Naruka IS, Shaktawat RPS. Effect of row spacing and nitrogen on growth and yield of coriander (Coriandrum sativum L.). J Krishi Vigyan. 2016; 5(1):49-53, DOI : 10.5958/2349-4433.2016.00032.5

22. Singh A, Ramphal, Yadav AC. Comparative performance of new okra variety HRB-108-2 with standard variety Varsha Uphar under different levels of nitrogen and plant spacing. Haryana J Horti. Sci. 2005; 34:387-388.

23. Tatero K, Ojima M. Growth analysis of grain sorghum as affected by planting density and amount of nitrogen. Proceedings of the crop sci. society of Japan. 1973; 42(4):555-559.

24. Tehlan SK, Thakral KK. Effect of different levels of nitrogen and leaf cutting on leaf and seed yield of coriander (Coriandrum sativum L). J of Spices and Aromatic Crops. 2008; 17(2):180-182. 